\title{
11. Recent developments in U.S. labor policies and programs
}

\author{
Christopher T. King and Burt S. Barnow
}

\subsection{INTRODUCTION}

This chapter describes developments in labor policies in the United States. It focuses primarily on policies and programs during the Obama Administration (from 2009 through 2017) and the Trump Administration (2017-21). ${ }^{1}$ The second section presents and discusses conceptual underpinnings for these policies. The next section summarizes the evolution of the U.S. Department of Labor's (USDOL) evaluation policies from the late 1960s to the present. This is followed by a discussion of the most recent major U.S. employment and training programs, the Workforce Investment Act (WIA) and its successor, the Workforce Innovation and Opportunity Act (WIOA) and evaluations of WIA and promising employment and training strategies. Next is a discussion of evaluations of large-scale demonstrations of employment and training programs for welfare recipients and other low-income populations, Pathways for Advancing Careers and Education (PACE) and Health Profession Opportunity Grants (HPOG). This is followed by a review of programs intended to reduce costs for Unemployment Insurance (UI) programs and increase employment and earnings for recipients. The next section discusses performance measurement for U.S. employment and training programs and recent developments in the performance measurement approach. The final programmatic section discusses policies for regulating wages and hours by the U.S. Department of Labor in recent decades. The last section offers conclusions and shares lessons learned, some of which may well be applicable in other countries. It also reflects on the United Nations' principles for effective governance.

\subsection{CONCEPTUAL UNDERPINNINGS}

By and large, economists and policymakers in the United States in the late 19 th and early 20th centuries deferred to "free markets" to find the right levels of employment and unemployment in the wider economy, to set wages and 
hours, and to establish appropriate conditions for workers on the job, although there was growing concern, referred to as the "liberal consensus," that markets might need added help from governments. ${ }^{2}$ This assistance could range from action to help stabilize markets in times of recession or panic (macroeconomic) to intervening when private markets experienced various forms of failure due to things such as externalities (microeconomic). With little action at the federal level, states began enacting laws to govern maximum hours and minimum wages, but these were challenged and mostly struck down by the U.S. Supreme Court in a series of important rulings.

The Great Depression, which began in late 1929 and deepened during the 1930s, led President Roosevelt to press for broad market stabilization measures as well as greater regulation in the workplace. The U.S. Congress responded with the National Industrial Recovery Act of 1933, only to have it struck down by the courts in 1935. Two years later, the Supreme Court reversed its 1923 decision in West Coast Hotel v. Parish (1937), allowing a Washington State minimum wage law for women to stand. This ushered in the end of the Lochner Era and paved the way for the Fair Labor Standards Act of 1938 as part of Roosevelt's New Deal. The New Deal also instituted massive job creation efforts including the Works Progress Administration, the Civilian Conservation Corps, and Rural Electrification, as well as Social Security and relief for jobless citizens in the form of Unemployment Insurance. If not fully grounded in newly emerging Keynesian macroeconomic theory, these were large-scale, highly pragmatic efforts to address market failures. ${ }^{3}$

Historical antecedents of workforce development policies date from the 1920s and late 1930s, but modern-day policies were initiated in the early 1960s. Referred to then as "manpower policies," early efforts began by addressing geographic pockets of poverty and workers displaced due to technological change before President Johnson's Great Society and War on Poverty shifted their focus more emphatically to meeting the needs of the poor and the unemployed (Clague and Kramer, 1976). There was growing recognition in policy circles that market forces alone were insufficient to address the problems of persistent unemployment and poverty. The workforce toolkit was enhanced over time with considerable bipartisan support to include skills training, on-the-job training, and work experience, as well as direct job creation (e.g., public service employment in 1973). However, by the early 1980s, the Reagan Administration began to circumscribe public job creation efforts dramatically, eliminating them from the federal budget in 1981 and from the list of allowable activities with the passage of the Job Training Partnership Act in 1982. ${ }^{4}$ This reflected its belief in "supply side" economics and its return to greater reliance on market forces from several decades of more interventionist policies, reliance that largely continued during the Administrations of George H.W. Bush (1989-93) and George W. Bush (2001-09). The recent Democratic 
presidencies of Bill Clinton (1993-2001) and Barack Obama (2009-17) generally reflected a return to more proactive workforce development and workforce regulation. The Obama Administration, in particular, was confronted with the Great Recession and worked with the Congress to enact large-scale job creation and recovery programs at funding levels that could not have been foreseen just a few years before (Barnow and Hobbie, 2013).

The 2017-21 Trump Administration strongly deemphasized the need for regulating wages, hours, and working conditions, deferring instead to employers to "do right" by their employees. This more business-friendly approach appeared to have the potential to usher in a new Lochner Era, given the increasingly conservative, employer-friendly makeup of the Supreme Court. However, the election of a new president, Joseph Biden, in November 2020 is likely to result in a further re-setting of the labor policy agenda.

\subsection{EVOLUTION OF DEPARTMENT OF LABOR EVALUATION POLICIES}

In the 1960s, individual agencies of USDOL were responsible for research and evaluation of their own policies and programs. Employment and training programs were largely the responsibility of what was initially called the Manpower Administration, and later renamed the Employment and Training Administration (ETA). ETA had a large staff devoted to research and evaluation, peaking at approximately 300 . However, the staff and funding available were greatly reduced over time, falling to under a dozen staff members by the early 1990s. The budget for external research and evaluation was also reduced and by the 1980s most research and evaluation was conducted through grants and contracts. ${ }^{5}$

Beginning in the 1960s, USDOL also had a central staff in the Office of the Secretary of Labor that focused on research and evaluation. Initially known as the Office of the Assistant Secretary for Policy, Evaluation, and Research (ASPER), the office was renamed as the Office of the Assistant Secretary for Policy (OASP) in 1981, with less emphasis on research and evaluation. In 2010, OASP's evaluation focus was expanded considerably with the creation of the Chief Evaluation Office (CEO), which had responsibility for evaluation activities across the entire department. Funds for evaluations of ongoing programs, demonstrations, and pilot projects were largely transferred to CEO. Between 2010 and 2017, CEO completed 87 studies, spanning a wide range of USDOL areas: workforce and education (33), labor market trends and the future of work (13), occupational safety and health (7), mining safety and health (3), wage and hour issues (6), family leave (6), and unemployment insurance (3). In early 2019 , there were 40 ongoing studies in CEO. ${ }^{6}$ 
The CEO buildup took place during the Obama Administration (2009-17). The Trump Administration (2017-21), however, deemphasized program evaluations. The annual funding available for evaluations was $\$ 13$ million to \$26 million in the last two years of the Obama Administration but by 2019 had been reduced to around $\$ 2$ million.

\subsection{WORKFORCE DEVELOPMENT: THE WORKFORCE INVESTMENT ACT AND THE WORKFORCE INNOVATION AND OPPORTUNITY ACT}

Beginning in the 1960s, the United States has had a series of federally funded employment and training programs administered at the state and local levels. The focus here is on the two most recent programs, WIA and its successor, WIOA. WIA was enacted in 1998 to replace the Job Training Partnership Act (JTPA). Like its predecessors, WIA used formulae based on unemployment and the size of the population to distribute funds to states and sub-state areas, where services were delivered. WIA had three separate funding streams for Adults, Dislocated Workers, and Youth.

A key feature of WIA was the utilization of a one-stop delivery system that required many workforce development programs to co-locate and coordinate services in One-Stop Career Centers, which USDOL recently rebranded as American Job Centers (AJCs). The One-Stop centers were intended to provide the "core" and "intensive" services mandated by WIA (described below); to provide access to workforce development programs and services offered by One-Stop partners; and to provide access to the labor market information, job search, placement, recruitment, and labor exchange services offered by the Employment Service (Bradley, 2013).

WIA established three levels of service that customers were required to access sequentially: (1) core services, including outreach, job search and placement assistance, and labor market information; (2) intensive services, including more comprehensive assessments, development of individual employment plans and counseling, and career planning; and (3) training services, including occupational training and training in basic skills. Participants who reached the third step generally used an "individual training account" (ITA) to select an appropriate training program from a qualified training provider.

Individual empowerment was an important feature of WIA, implemented largely through the ITAs. Local areas had great flexibility in administering the ITAs, and some local areas gave customers wide latitude in using their ITA, while others restricted customers in terms of cost, past performance of the vendor, and qualifications and aptitude of the customer for the course. ${ }^{7}$ 
Although WIA was originally authorized for just five years, 15 years passed before Congress and the Administration were able to agree on new legislation, the Workforce Innovation and Opportunity Act. Most of the new legislation became effective July 1, 2015. WIOA largely maintains the structure of WIA. WIOA also maintains separate funding streams for Adults, Dislocated Workers, and Youth, and requires activities at the state and local levels to be overseen by a board with a majority of the members from the private sector. Funds are distributed to the state and sub-state levels using formulae similar to those used under WIA.

The statute seeks to provide better services to jobseekers in several ways. First, WIOA promotes the use of career pathways programs and sectoral partnerships for training programs, two approaches that appear promising. ${ }^{8}$ Second, the statute allows states to transfer unlimited amounts of their grant between the Adult and Dislocated Worker programs. ${ }^{9}$ Third, WIOA adds basic skills deficiency as a priority category for participants, along with low income, for Adult services. Fourth, WIOA requires that 75 percent of Youth funds be used for out-of-school youth. Fifth, WIOA combines the core and intensive service categories under WIA into a new category called career services, and it abolishes the requirement that customers pass through core and intensive services before receiving training. WIOA also permits direct contracts with higher education institutions.

The WIA impact evaluation commenced in $2008,{ }^{10}$ and the 30 -month impact report was released in December 2018. ${ }^{11}$ The evaluation makes use of a randomized controlled trial (RCT) design. Instead of being assigned to treatment or control status, WIA participants at the evaluation sites were eligible for one of the three tiers of service offered under WIA (training, intensive services, and core services), as well as any lower tiers of service. Thus, the "full WIA" group could receive training, intensive, and/or core services, but the intensive services group could only receive intensive and core services through WIA. Second, people in the non-training tiers were eligible to receive training so long as it was not through WIA, and many in the intensive and core groups did receive training, though not as often as those in the full WIA group.

Unfortunately, the results of the impact evaluation of WIA do not indicate that the program is beneficial either to the participants or to society as a whole. Although WIA is sometimes referred to as a "training program," only 50 percent of those who were eligible received any training. Receipt of training for those in the core-plus-intensive-services group and the core-only group was somewhat lower, 41 percent and 34 percent, respectively. Because the contrast in training receipt was relatively small between the three groups, the report states that one should be cautious in interpreting the earnings impact estimates. However, given that the full WIA group earned about the same or less than the core-plus-intensive group in most quarters, it is difficult to find 
an optimistic interpretation of the findings. The only cause for optimism about the WIA program is that those eligible for intensive and core services earned more than those eligible for core-only services.

The report concludes that investments in intensive services, such as in-depth counseling and assessment, are worthwhile from both the individual and social perspectives, but that additional efforts need to be made to make the training provided under WIA and now WIOA more effective. In the next section, we provide evidence on some promising approaches to providing more effective training, such as career pathways programs and sector-based training.

\subsection{PROMISING APPROACHES TO TRAINING: SECTORAL STRATEGIES AND CAREER PATHWAYS}

While evaluation findings from national workforce evaluations have often been less than encouraging, sectoral and career pathway strategies have emerged as highly promising workforce approaches in recent decades (e.g., King, 2014; King and Prince, 2015). ${ }^{12}$ Often combining career pathways and sectoral training, they work to improve workforce program relationships with employers and postsecondary institutions. With the enactment and implementation of WIOA, these strategies have been embedded in national workforce policy and practice. Rigorous evaluations have documented their implementation as well as their impacts on employment, earnings, and other key outcomes.

\subsubsection{Strategies Described}

For most of their history, workforce strategies focused mainly on the supply side of the labor market. Local programs designed their activities and services in accordance with national and state policy, including job readiness, job search, and skills training via community and technical colleges, to address the needs of low-income and dislocated jobseekers, and then sought to place them with employers once their participation was nearing completion. Employers' needs were considered mainly as a secondary matter. The traditional approach to workforce policy and programming lacked two major pieces:

- Engagement with employers in key industries and sectors around common skill needs, that is, a focus on the demand side of the labor market; and

- Close collaboration with education and training providers (e.g., community and technical colleges), to ensure their offerings were structured to provide credentials valued by employers and sequenced and scheduled so that jobseekers could better navigate them. 
Sector-based workforce strategies, per Conway et al. (2007), target specific industries and/or clusters of occupations; typically intervene through credible organizations (often "workforce intermediaries"); support workers competing for quality job opportunities as measured by wages, benefits, and advancement opportunities; address employer needs and industry competitiveness; and create lasting change in labor market systems helping workers and employers. Sectoral strategies also act as integrators of wider regional economic and workforce development activities and are increasingly designed to be employer-led and demand-driven.

Career pathway strategies, which evolved later, tend to be either (King and Prince, 2015):

- Postsecondary-based, organized around articulated sets of courses that let individuals learn skills and earn credentials for specific occupations. Postsecondary career pathway programs identify key entry and exit points that allow individuals to reach a certain point in their pathway, leave for periods of work, and return for further education and training, with "stackable" credits and/or credentials toward completion of a particular diploma or degree. Success in this type of pathway is gauged by advancement through specified course work, credentials earned, job placement and retention, and earnings progression. ${ }^{13}$

- Employer-based, identifying occupations that have integrated career pathways and focusing more on preparing individuals for them based on completion of courses leading to industry-recognized credentials. Success for this type of pathway is measured by occupational placement and retention and later earnings gains.

Career pathway and sectoral strategies, while distinct, now tend to operate as integrated approaches to workforce development in a growing number of U.S. communities.

\subsubsection{Evaluation Results}

Evidence of the effectiveness of sectoral and career pathway strategies continues to grow, and findings from their evaluations are encouraging. One of the earliest evaluations of leading-edge programs in three sites by Maguire et al. (2010) indicated that:

- Participants earned significantly more $(\$ 4,500,18$ percent) than controls over two years following random assignment to treatment or control status and 29 percent more in year two;

- Participants were more likely to work, work more consistently (by year two), and work in jobs offering employee benefits; and 
- Employed former participants worked more hours and earned higher wages.

Several rigorous evaluations released since that review reinforce those findings. MDRC conducted an experimental evaluation of the WorkAdvance Demonstration that ran from 2011 to 2013 in New York (two sites), Ohio, and Oklahoma. Hendra et al. (2016) reported on impacts at a little more than two years post-random assignment, finding that the program:

- Led to large increases in participation in all services, as well as in training completion and credential acquisition;

- Increased earnings, with results varying with the providers' experience in running sector-based programs and the extent to which services offered were demand-driven; and

- Increased earnings among the long-term unemployed.

The "extent to which WorkAdvance increased employment in the targeted sector was the critical factor in explaining the pattern of impacts across the sites. At all sites, jobs in the targeted sector were generally of higher quality than jobs outside the targeted sector." Schaberg (2017) subsequently found that three-year earnings impacts for WorkAdvance showed considerable cross-site variation.

Another example of a program that provides skills training in a sectoral setting is San Antonio's Project QUEST, which enrolled its first participants in 1992. The program was explicitly designed as an employer-driven, sector-based strategy, initially in healthcare and hospitality. QUEST provides intensive career pathways skills training with stipends to offset the costs of training and foregone earnings. Roder and Elliott (2019) recently completed a nine-year experimental evaluation of Project QUEST in San Antonio and found:

- Large, statistically significant impacts on earnings, with gains continuing to grow over time: annual gains exceeded $\$ 5,000$ in the ninth year.

- Participants worked more consistently and earned higher hourly wages than those in the control group.

- Program participants' earnings grew from an average of $\$ 11,722$ to $\$ 33,644$ over the course of the evaluation. Those who completed the program earned an average of $\$ 46,580$ in the final year of the study, a level of earnings that translated into economic self-sufficiency in San Antonio.

- Those over 34 years of age and those with children experienced the greatest benefits from participation. 
Until recently, the evidence on the effectiveness of the career pathways approach was scattered and mixed; Eyster and Gebrekristos (2018: 2) conclude in a recent study that "evidence of longer-term outcomes, which could be supported through advancement programming, is limited. And the existing evidence is mixed." Recently, however, researchers have been undertaking a synthesis of research and evaluation studies on career pathways programs. The design of the project is summarized in Schwartz et al. (2018).

PACE is composed of nine individual programs. Initial impact estimates on outcomes such as enrollment and credential attainment for individual PACE programs have been mixed. Seattle-King County's Health Careers for All program produced no impacts on either hours of training received or credentials attained at 24 months after random assignment (Glosser et al., 2017), for example, while participants in the Valley Initiative for Development and Advancement (VIDA) program in Texas' Lower Rio Grande Valley experienced higher rates of college enrollment, including full-time enrollment, and earned 5.6 more college credits and more college credentials (Rolston et al., 2017). Fein and Hamadyk (2018) recently found that Year Up substantially increased participation in training services across the eight sites relative to controls and produced significant gains in quarterly earnings - nearly $\$ 1,900$ or 53 percent - in the sixth and seventh quarters after random assignment. Year Up earnings gains were sustained through the third follow-up year as well. ${ }^{14}$ Employment and earnings impact estimates for the various PACE programs have varying and somewhat uncertain release dates; only the initial round of post-assignment follow-up has been funded by the US. Department of health and Human Services.

\subsection{SUMMER YOUTH EMPLOYMENT PROGRAMS}

Although the United States no longer has a dedicated summer employment program for poor youth, many local areas operate such programs, using a variety of federal, state, and local funding sources. In large cities, there is often excess demand for the summer jobs, and the cities have frequently made use of lotteries to ration the scarce slots. Researchers have noted that, if properly administered, lotteries are equivalent to random assignment, and by linking program application and participation data with administrative data from state and local agencies, they have been able to evaluate the summer youth programs for several outcomes, including employment and earnings, arrest records, school attendance, and graduation. Here we highlight findings from several of these evaluations.

Gelber et al. (2016) analyze the impact of New York City's summer youth program for 2005 through 2008 on earnings, employment, college attendance, incarceration, and mortality. They find that participation in the program raises 
net earnings in the year of participation by $\$ 876$ and increases the probability of having any job in the year of participation by 71 percent. Counterintuitively, they find that participation in the summer youth program reduces earnings in the three years following participation by approximately $\$ 100$ annually, and after that has no effect on earnings. The authors also find that the program has no impact on college enrollment, reduces incarceration by 0.098 percentage points, and reduces mortality by 0.073 percentage points; the reductions in incarceration and mortality are concentrated among male participants. Although the percentage reduction in mortality appears small, the findings imply that 83 lives were saved for the four years of the program studied, and given the findings from studies of the value of life, the social benefits of the reduced mortality alone are estimated to be $\$ 747$ million.

Schwartz et al. (2015) also analyzed the effects of participation in the New York City summer youth program from 2005 through 2008, but their study focused on the impact of the program on academic outcomes. They find that "participation in SYEP has, on average, a positive, albeit small, effect on taking and passing the standardized tests administered by New York State to measure progress in high school subjects" (2015: 24-5). When they look separately at students who were enrolled in the program for the first time and those who enrolled more than once, they found little effect for those in the program one year, but much larger impacts for those enrolled more than once.

Heller (2014) analyzed the impact of a summer youth program in Chicago on the incidence of crime. She found that the eight-week summer job program decreased violence by 43 percent over a 16-month period; this was equivalent to a reduction of 3.95 fewer crime arrests per 100 youth over the period. Interestingly, the decline in violent crime largely occurred after the eight-week program ended.

The studies summarized above do not indicate that all summer youth employment programs have large impacts in a variety of areas, but they do indicate that these programs can have large impacts and pass a cost-benefit test. Because the programs are often oversubscribed, the opportunities for relatively inexpensive evaluations using random assignment and linking program data to income, health, crime, and education administrative records data should be vigorously pursued so that more can be learned about the effectiveness of these programs.

\subsection{ACTIVITIES AND SERVICES FOR UNEMPLOYMENT INSURANCE CLAIMANTS}

The U.S. Unemployment Insurance (UI) program provides cash assistance to eligible workers who lose their jobs through no fault of their own. To receive benefits, workers must have enough covered employment in recent calendar 
quarters, they must be able and available for work, and they must actively search for work. There are some conformity requirements imposed by the federal government, but states have wide latitude in shaping key provisions of their programs including monetary and non-monetary eligibility requirements, the size and duration of benefits, and penalties for non-compliance by claimants. The state UI programs are primarily financed by state payroll taxes on employers, but there is also a federal payroll tax that pays for implementation of the system. In this section, we describe two recent initiatives in the UI area intended to improve labor market outcomes for claimants and to reduce UI costs - (1) initiatives intended to improve compliance with UI eligibility rules and provide employment services to claimants, and (2) an initiative using behavioral principles to increase compliance with attendance rules in these programs.

Since 2004, USDOL has sponsored a series of voluntary activities by states that are intended to save UI payments to claimants and improve labor market outcomes (employment and earnings) for claimants. These programs were originally referred to as Reemployment and Eligibility Assessment (REA), but in 2016 the initiative was renamed Reemployment Services and Eligibility Assessments (RESEA). States have a great deal of flexibility with how they use their REA/RESEA grants, but the underlying concept is that they should engage claimants early in their unemployment spell, both to verify eligibility and provide assistance in finding a new job.

Prior evaluations of REA showed that the program is very effective in reducing UI costs and improving employment and earnings for claimants. USDOL recently funded an evaluation of REA/RESEA to refine knowledge about the program's effectiveness. The earlier study is referred to as the REA evaluation, and the newer study is referred to as the RESEA evaluation. The REA study was initiated to determine the effectiveness of REA strategies on claimants and to determine which features of REA drive the results. The REA demonstration was implemented in four states (New York, Indiana, Washington, and Wisconsin), with sample sizes ranging from 26,000 to 70,000 . Claimants determined eligible for participation were randomly assigned to one of four treatment streams:

- Partial REA, where the claimant was called in for a brief session to establish eligibility for benefits;

- Full REA, where the claimant received eligibility assessment and some services to help find a job;

- Multiple REAs, where the claimant was called in periodically over their UI spell for additional reemployment services;

- Control status, where the claimant was informed that they were responsible for searching for work but were not called in. 
The demonstration operated for approximately one year in each state, and follow-up data for participating claimants was gathered for up to one year after the initial claim was filed. Major findings from the REA evaluation are:

- REA cuts UI durations, but the estimates vary substantially (ranging from about 1.5 weeks to 0.5 weeks) among the four states;

- REA raises short-term employment and earnings, but the magnitude is a small percentage of earnings (about 2 percent);

- About half the decrease in UI weeks is due to an increase in employment; the other half is due to more time neither receiving UI nor employed;

- Both the enforcement and assistance components affected UI payments and duration as well as employment and earnings;

- REA has small positive impacts on employment past the benefit year.

A problem that has commonly been observed in REA and RESEA programs is that claimants frequently do not show up for appointments to have their eligibility verified and to receive services. In a demonstration in Michigan, USDOL funded a project to understand why people did not show up for required meetings and to develop and test a strategy to improve attendance. The demonstration was undertaken in the Michigan Works! Southwest region of Michigan by a team of researchers at Mathematica Policy Research and their subcontractors. The researchers first conducted interviews with and observations of claimants and staff to identify the reasons for low attendance. Darling et al. (2017) found that low attendance resulted from avoidance of unpleasant tasks; inattention, procrastination, and forgetfulness; and misunderstanding of the REA rules. A random sample of roughly 750 claimants was randomly assigned to either receive the usual REA treatment or to receive a redesigned REA experience that included positive tone in the invitation letter, concise instructions on what the claimant was to do to meet the REA requirements, reminder messages to reduce avoidance behavior, and planning prompts to encourage productive job search. The demonstration showed that the redesigned program increased attendance at the initial meeting from 55 percent to 71 percent, and the proportion completing the REA program increased from 43 percent to 57 percent.

\subsection{APPROACHES TO WORKFORCE PERFORMANCE MEASUREMENT, OLD AND NEW}

Workforce development programs have a long track record of measuring and managing performance, dating from initial trial efforts in the late 1970s and early 1980s under the Comprehensive Employment and Training Act of 
1973 and evolving under the Job Training Partnership Act of 1982. ${ }^{15}$ WIA and WIOA have continued this evolution.

Motivation for incorporating systematic performance measurement and management in workforce development programs stems from several factors, including:

- Gauging, understanding, and fostering improvements in program performance;

- Minimizing principal-agent problems;

- Eliminating perverse incentives (e.g., cream-skimming);

- Identifying good and bad programs; and

- Rewarding good programs and penalizing bad ones.

The initial effort in developing performance measurement and management approaches for the U.S. workforce system was conducted mainly by economists, so they are different from later efforts instituted for programs across the federal government under the Government Performance and Results Act of 1993. Table 11.1 offers an overview of performance measures under three different regimes from the early 1990s to 2017 to give a sense of how these measures have changed over time. The table and following discussion focus mainly on adult workforce programs.

As shown, JTPA performance measures were specific to adults, adults on welfare, and youth. While performance measurement under JTPA initially focused only on performance immediately at the point of program exit, it soon shifted emphasis to a period up to six months after exit, relying on telephone surveys of former participants to provide the data. The WIA statute initially called for customer satisfaction measures for all programs and for attainment of recognized occupational credentials for adults, but these were dropped after the USDOL adopted the "common measures" promulgated by the federal Office of Management and Budget in 2005. In addition, under WIA, administrative records collected for the UI program became the primary data source for measuring employment and earnings performance across the country. WIOA in 2014 modified the measurement points and introduced new measures on credential attainment and skill gains and provided for employer service effectiveness measures that are still being formulated. 
Table 11.1 Adult workforce performance measures under JTPA, WIA, and WIOA

\begin{tabular}{|c|c|c|}
\hline JTPA (early 1990s) & $\begin{array}{l}\text { WIA (late 2000s with "Common } \\
\text { Measures") }\end{array}$ & WIOA (2017) \\
\hline $\begin{array}{l}\text { Adult (13-week) Follow-Up } \\
\text { Employment Rate }\end{array}$ & $\begin{array}{l}\text { Entered Employment Rate } \\
\text { 1st Quarter after Exit (Adult } \\
\text { Programs) }\end{array}$ & $\begin{array}{l}\text { Employment Rate 2nd Quarter } \\
\text { after Exit (Adult Programs) }\end{array}$ \\
\hline $\begin{array}{l}\text { Adult (13-week) Follow-Up } \\
\text { Weekly Earnings }\end{array}$ & $\begin{array}{l}\text { Employment Retention 2nd \& } \\
\text { 3rd Quarters after Exit (Adult } \\
\text { Programs) }\end{array}$ & $\begin{array}{l}\text { Median Earnings 2nd Quarter } \\
\text { after Exit (All Programs) }\end{array}$ \\
\hline $\begin{array}{l}\text { Welfare Adult (13-week) } \\
\text { Follow-Up Employment Rate }\end{array}$ & $\begin{array}{l}\text { Six Months Average Earnings } \\
\text { Increase 2nd \& 3rd Quarters after } \\
\text { Exit (Adult Programs) }\end{array}$ & $\begin{array}{l}\text { Employment Rate 4th Quarter } \\
\text { after Exit (Adult Programs) }\end{array}$ \\
\hline \multicolumn{3}{|l|}{$\begin{array}{l}\text { Welfare Adult (13-week) } \\
\text { Follow-Up Weekly Earnings }\end{array}$} \\
\hline & & $\begin{array}{l}\text { Placement in Employment or } \\
\text { Education up to } 1 \text { Year after } \\
\text { Exit (All Programs, except } \\
\text { Wagner-Peyser) }\end{array}$ \\
\hline & & $\begin{array}{l}\text { Measurable Skill Gains (All } \\
\text { Programs, except Wagner-Peyser }\end{array}$ \\
\hline & & $\begin{array}{l}\text { Credential Attainment Rate (All } \\
\text { Programs) }\end{array}$ \\
\hline & & $\begin{array}{l}\text { Effectiveness in Serving } \\
\text { Employers (All Programs) }\end{array}$ \\
\hline
\end{tabular}

Source: USDOL Training and Employment Guidance Letters (TEGLs): TEGL \#17-05, Change 2 (May 20, 2009); and TEGL \#10-16, Change 1 (August 23, 2017); and King and Barnow (2011).

Additional trends in performance measurement and management include:

- A shift toward use of longer-term outcomes with no measures at the time of exit and a measure as far out as the fourth quarter following exit;

- Focus on credential attainment and skill gains;

- Use, abandonment, and return to the use of statistical models to adjust or "hold programs harmless" for conditions outside their control;

- Stressing sanctions (negative) over rewards/incentives (positive) to foster improved performance: WIOA only features sanctions;

- Deemphasizing efficiency (so-called "cost-per") measures: these were dropped from JTPA in the 1980s and reconsidered briefly but not adopted under WIA; and

- Dropping satisfaction measures for participant and employer customers, but later adding measures of the quality of services to employers. 
Employer measures merit further discussion. The WIOA legislation calls for an employer effectiveness measure, a provision that reflects growing concern that, while WIA and WIOA both emphasize a "dual customer" focus for workforce development programs, an employer measure (other than a satisfaction measure) has never been used. After consultation with experts and holding discussions in a number of national and regional convenings, the USDOL opted to proceed with caution. It is currently piloting three employer effectiveness measures:

- Employer Penetration Rate: the share of establishments in a state/local workforce area receiving workforce services;

- Repeat Business Customers: the share of all establishments in a state/local workforce area receiving a workforce service which received a service in the previous three years; and

- Retention with the Same Employer: the share of participants who exit and are employed with the same employer in the 2 nd and 4 th quarters after exit.

States must select two of the three measures above to use with their programs and may develop and pilot their own measures of employer effectiveness as well.

\subsection{REGULATING WAGES, HOURS, AND CHILD LABOR}

\subsubsection{Administrative Structure and Mission}

Regulating wages, hours, and conditions of employment (including child labor) has been a core function of USDOL for more than eight decades as part of the Wage and Hour Division (WHD), which was established in 1938. The Wage and Hour and Public Contracts Divisions were created by order of Secretary of Labor Frances Perkins in October 1942, consolidating several offices, to administer federal minimum wage, overtime pay, and child labor laws. ${ }^{16}$ Its mission is "to promote and achieve compliance with labor standards to protect and enhance the welfare of the Nation's workforce." ${ }^{17}$ The WHD is responsible for:

- Enforcing the federal minimum wage, overtime pay, recordkeeping, and child labor requirements of the Fair Labor Standards Act (FLSA) of 1938, as well as the Migrant and Seasonal Agricultural Worker Protection Act, the Family and Medical Leave Act (FMLA), wage garnishment provisions of the Consumer Credit Protection Act, and other employment standards and worker protections in immigration-related statutes. 
- Administering and enforcing the prevailing wage requirements of the Davis Bacon Act and other federal contracting statutes.

The WHD has more than 200 regional and district offices around the country and its territories. While some of the less populated states (e.g., North and South Dakota) lack offices, a number of the larger ones (e.g., California, Florida, Texas) have several WHD offices. About half of its almost 2,200 employees (measured in full-time equivalents) are investigators, reflecting its mission. A 2010 restructuring created new leadership positions in the WHD in planning, policy, and operations (USDOL, 2010: 92).

There has been little nuance in the staffing, regulatory approach, caseloads, or outcomes for the WHD since the late 1990s. Four distinct eras are evident: the late Clinton Administration under Secretary Alexis Herman; the Bush II Administration under Secretary Elaine Chao; the Obama Administration under Secretaries Hilda Solis and Tom Perez; and the Trump Administration under Secretaries Alex Acosta and Eugene Scalia. Cabinet secretaries typically join the administration with agendas and priorities, having negotiated with the President and his domestic leadership team in the White House. Secretary Herman came directly from the White House staff and had enjoyed support from the President; she had also served in the USDOL previously as director of the Women's Bureau in the Carter Administration under Secretary of Labor Ray Marshall. Secretary Chao, the spouse of the Senate majority leader Mitch McConnell (Rep.-KY, 2015-21) and Secretary of Transportation under Trump, came into the USDOL with a background in transportation and no particular agenda other than serving an administration strongly favoring business and shrinking domestic agency budgets. Chao's commitment to the mission and work of WHD was less than complete. Solis, a feisty, former Democratic Congresswoman from southern California, who had grown up in poverty, had long been fighting for better wages and working conditions for low-paid, low-skilled workers. After a protracted confirmation battle she was confirmed and immediately began working to "restore" regulation of wages, hours and working conditions, although she was less engaged in workforce and immigration discussions, including ARRA. Perez brought a remarkably broad resumé to the position, as a former civil rights attorney with the U.S. Department of Justice, and a former Maryland cabinet secretary for workforce development. Perez evidenced strong interest on all fronts at the USDOL and energetically pressed the concerns of low-wage and middle-class workers.

\subsubsection{Regulatory Approach}

WHD's approach to regulation has changed dramatically since the early 1990s, with the most important advances taking place in the last six years of 
the Obama Administration and the ones least supportive of workers and their interests - not just on wage and hour regulation but on many other fronts affecting worker protections in and outside of USDOL — brought forth under the Trump Administration between 2017 and 2021.

During the Clinton Administration in the 1990s, WHD pursued a relatively traditional approach to regulation, relying heavily on complaints being filed with some targeting of low-wage sectors. Under the George W. Bush administration from 2001 to 2009, regulation remained complaint-driven, with a steady erosion in staffing and a concomitant drop in complaints filed and cases closed, and a rise in the number of closed cases with "no violation." Rhetoric aside, it was an open secret that USDOL in this period was less committed to enforcing labor laws and that this was going to be an era of laissez-faire for wage and hour enforcement, as well as other areas involving worker rights and safety.

There was a marked shift in philosophy and approach under the Obama Administration, as well as a noticeable uptick in WHD activity. The administration took its cues from the work of former Boston University professor David Weil and his team of researchers, ${ }^{18}$ adopting a more proactive and strategic approach than in preceding administrations in early 2009 . Weil, who was named WHD administrator in 2014, had been advising the USDOL on WHD issues for several years, and he authored an influential 2010 report explaining the complex labor market and regulatory environment that had emerged in the past few decades and the challenges it presented for identifying and understanding violations of the laws and regulations on wages and hours, for educating workers and employers, and for enforcement. Based on four years of analysis by teams of researchers, his report offered six major findings (Weil et al., 2010: 1-2, emphasis added):

1. Changes in the structure of the economy and in the complexity of employment relationships, as well as the decline in unionization together render the traditional, workplace-focused approach to enforcement less and less effective. At the same time, the changing expectations of Congress, the OMB, key stakeholders, and the public have raised the performance demands on agencies like WHD. As a result, traditional approaches to enforcement are no longer sufficient, even given the significant increase in enforcement resources.

2. The employment relationship in many sectors with high concentrations of vulnerable workers has become complicated as major companies have shifted the direct employment of workers to other business entities that often operate under extremely competitive conditions. This "fissuring" or splintering of employment increases the incentives for employers at lower levels of industry structures to violate workplace policies, including the FLSA. Fissuring means that enforcement policies must act on higher levels of industry structures in order to change behavior at lower levels, where violations are most likely to occur.

3. Deterring violations before they occur has long been recognized as part of overall enforcement policy, but has often not been incorporated as a central 
component of how investigations are targeted, conducted, and followed up on, or in the way that penalties are assessed and levied. As a result, deterrence incentives are often low, uneven, and inconsistent. There are many opportunities to significantly enhance deterrence incentives, particularly at the industry level.

4. The structure of industries - particularly the way that "fissuring" plays out in them-has important implications for strategic enforcement. Analysis of the structures of industries can give guidance on why some employers comply and others do not. These insights, in turn, can help shape sector-based enforcement strategies and policies to change employer behavior and improve compliance systemically. The impact of supply-chain relationships, branding, franchising, third-party management, and subcontracting all have important implications for patterns of compliance in an industry and for strategies that WHD can take to affect employer behavior.

5. The two main types of investigations undertaken by WHD - directed and complaint - have often been treated as separate and distinct. Strategic enforcement and the demands placed on the agency by oversight institutions and the public require integration of these key tools of enforcement, particularly in the way they are undertaken in the context of specific industries and initiatives.

6. The external and internal changes in the environment in which WHD operates require new criteria for judging the success of enforcement initiatives. In particular, enforcement strategy should be guided and evaluated on the basis of the following four criteria: prioritization; deterrence; sustainability; and system-wide impacts.

Recommendations from Weil's report spanned three broad areas of WHD activity, encompassing not only enforcement, but education and other activities as well:

- Setting industry priorities for all levels of the WHD (i.e., national, regional, and district) using three criteria: (1) sectors with large concentrations of vulnerable workers; (2) sectors where the workforce is particularly unlikely to step forward (e.g., industries with concentrations of new immigrants); and (3) sectors where the WHD is likely to be able to change employer behaviors in a lasting and systemic manner.

- Implementing more strategic enforcement strategies, including focusing on the top of industry structures, enhancing deterrence at all levels, better integrating complaint and directed investigation activities, and enhancing the sustainability of enforcement to change employer behavior; and

- Making substantial organizational changes, including better training and investigative capacity, stronger coordination with the USDOL Solicitor, improved coordination between the main and district WHD offices, better information systems to support investigation and planning, joint efforts with other agencies, and systematic use of evaluations.

Weil's recommendations were reflected in the WHD and its regulatory approach through 2016, which involved a mix of enhanced education for 
workers and employers; strategic targeting by industry sectors, stressing both low-wage and repeat offenders; and a shift to directed or agency-initiated over more passive, complaint-driven regulation. It also incorporated aggressive use of social media to strive for "ripple effects" throughout industry from its enforcement successes and related actions (Weil, 2014a, 2014b). The agency's regulatory agenda — referred to as Plan/Prevent/Protect—replaced the earlier approach, characterized as "catch-me-if-you-can" (USDOL, 2010: 100-101):

- The WHD asks employers and other regulated entities to create a plan to "find and fix" violations before the WHD investigators become involved.

- Employers must implement these plans to prevent violations of the law.

- Employers must assure that their plans protect workers.

The WHD devoted considerable time and energy in the Obama Administration to addressing such issues as: misclassification of employees as independent contractors, delving further into the "fissuring" of the employment relationship, and clarifying the definition of "spouse" for employee benefits, as the overwhelming majority of states in the country have legalized same-sex marriage. Minimum wage enforcement was also a key focus.

Under Secretaries Acosta and Scalia, key positions within WHD have remained vacant for extended periods, ${ }^{19}$ including the WHD Administrator position - that was finally filled in late April 2019, just weeks after a nomination was made - or have been filled by acting personnel. Claims for wage and hour law violations have continued to be filed and acted upon.

The Trump Administration appeared to pursue a 10-point agenda put forth by the U.S. Chamber of Commerce for the National Labor Relations Board (U.S. Chamber of Commerce, 2017), the independent agency charged with protecting worker rights to organize and bargain collectively (McNicholas et al., 2019). By 2020, all ten items on the Chamber's agenda had either been implemented or were "in process," including overturning a ruling to give employers greater say in determining bargaining units, weakening rules adopted in 2015 that streamlined union representation elections, and allowing forced arbitration and others. Among other actions, the Trump Administration also withdrew a 2016 federal rule that would have raised the annual salary threshold for overtime pay eligibility to over $\$ 47,000$ and thereby would have expanded overtime coverage to an estimated 13 million workers. According to the Economic Policy Institute, overtime pay protections had eroded dramatically since the early 1970s to the point that it was less than the poverty level for a family of four (McNicholas et al., 2017).

Under federal law, almost all hourly workers are automatically eligible for overtime pay, but salaried workers are only automatically eligible if their earnings fall below a certain salary threshold. Salaried workers who earn 
above the threshold are eligible for overtime protections only if they are not a manager, supervisor or highly trained professional. The final overtime rule, issued by USDOL on September 24, 2019, establishes the salary threshold for salaried workers to be automatically eligible for overtime pay at just $\$ 35,568$ annually. EPI estimates this new lower threshold will exclude 8.2 million workers, including " 4.2 million women, 2.7 million parents of children under the age of 18, 2.9 million people of color, and 4.6 million workers without a college degree" (Shierholz, 2019).

The Trump Administration also initially rolled back Obama Administration fiduciary rules originally proposed in April 2016 to protect workers and retirees from investment advisor conflicts of interest. The financial industry voiced strong opposition to the proposed rules that were expected to increase the numbers and types of advisors subject to fiduciary rules and also to reduce commissions they were going to earn. The 5th Circuit Court of Appeals vacated the proposed rules in March 2018 in a lawsuit filed by the U.S. Chamber of Commerce and other business groups as "unreasonable." The USDOL now appears to be working with the Securities and Exchange Commission (SEC) to modify these rules and "bring them into alignment" although it is unclear when this is likely to happen. The Administration also delayed implementation of numerous worker safety and health regulations, including those governing exposure to silica.

Finally, in August 2018, USDOL Solicitor (SOL) Kate O'Scannlain issued a memorandum directing SOL staff to notify her office of pending enforcement actions (e.g., Equal Employment Opportunity, WHD, OSHA) in situations where employees have signed mandatory arbitration agreements as part of their employment contracts with their employers (such agreements typically allow employers to select the arbitrator unilaterally). In these situations, USDOL will decline to be involved in their cases. This essentially reissues the memorandum that was prepared in the Bush II Administration in 2005 by then-Solicitor Eugene Scalia, the former Secretary of Labor. The prevalence of such agreements has grown rapidly in recent decades. While the share of private sector, non-union workers in mandatory arbitration agreements was 2 percent in 1992, it had grown to almost a quarter in the early 2000s and exceeded 56 percent in 2017 (Colvin, 2017). By 2024, EPI estimates that more than 80 percent of private sector workplaces are likely to have such agreements in place. This effectively denies these workers the protections of most federal worker protection, civil rights and other statutes.

The WHD also began making greater use of the Internet and various digital technologies, including smartphone applications related to the FLSA enforcement data and worker-accessible time sheets, in order to broaden its reach under Mr. Weil prior to 2017. It is unclear whether those efforts were continued under the Trump Administration. 


\subsection{CONCLUSIONS AND LESSONS LEARNED}

The U.S. Department of Labor has pursued a variety of policies and issues since the 1960s. Beginning in the 1960s, employment and training expanded from only providing labor exchange services to including federal support for a number of training programs administered at the state and local levels. Evaluations of employment and training programs have helped identify promising approaches that have been tested using rigorous methods in recent decades; current efforts focus largely on career pathways programs and sectoral training programs that include input from industries covered to assure that the training is demand-driven. Recent evaluations appear to show that the formula-funded training may not do well at increasing employment and earnings, but some evaluations of demonstrations have shown considerable success, as have evaluations of summer youth employment programs. USDOL has been a leader in performance measurement, implementing and evaluating performance measures to provide accountability and encourage programs to improve their performance. ${ }^{20}$

In recent years, efforts have been made to improve the Unemployment Insurance program through pilot programs that increase enforcement and provide services to claimants, and evaluations thus far have been promising. As the economy and structure of the labor force have changed in recent years, some have argued that USDOL's regulation of issues such as the minimum wage and overtime became obsolete. During the Obama Administration, efforts were made to change how such laws were enforced, but the Trump Administration reversed some policies and left many key positions in USDOL and other cabinet agencies unfilled. Although workforce policies and programs have not changed much in recent years, efforts to improve programs through rigorous evaluations and performance management have helped identify which programs are working well and which are not.

A number of lessons can be gleaned from this examination. First, regarding worker rights and protections, it is far easier to dismantle a supportive infrastructure of legislation, regulations, and staffing than it is to construct one. It also takes far less time. The United States began building the infrastructure in support of workers and their institutions during the Progressive Era more than one hundred years ago and continued to strengthen it during the New Deal in the 1930s. USDOL policy implementation took a major step forward modernizing and streamlining its approach to labor regulation in the later Obama years, led by WHD Administrator David Weil and his team. The Trump Administration, with active support from the new conservative majority on the U.S. Supreme Court and a National Labor Relations Board dominated by employer-leaning members, severely weakened the infrastructure supporting 
workers, undermining the leadership within USDOL and diluting or rolling back key worker protections.

Second, to fully understand the nature and scope of changes in policies affecting workers - whether for workforce development, labor regulation or other arenas - it is necessary to consider the broader context within which these changes are taking place. Often, the biggest shifts are signaled not by official policy modifications but rather by leadership and staffing developments, through internal memoranda and by related court actions. This is certainly the case with labor regulation: it may not be necessary to pursue changes via the usual regulatory process if the desired results can be achieved through other means.

Finally, a few comments are in order about how our findings relate to the United Nations' 2019 Principles of Effective Governance for Sustainable Development, an effort that, at least in part, led to the research for this book. These 11 principles - which are organized into three broad areas of effectiveness (competence, sound policy making, collaboration), accountability (integrity, transparency, independent oversight), and inclusiveness (leaving no one behind, non-discrimination, participation, subsidiarity, intergenerational equity) - "are linked to a variety of commonly used strategies for operationalizing responsive and effective governance" (United Nations Economic and Social Council, 2019). The long-running emphasis on program evaluation, performance management, and evidence-based policy making at the U.S. Department of Labor, especially in its many workforce development programs but also with the creation of the Chief Evaluation Office (CEO), fully resonates with the first two principles of effectiveness and accountability, and its programmatic focus on serving economically disadvantaged and other population groups affected by economic dislocation does so with the inclusiveness principle as well. It is less clear where things stand at present with these principles in terms of administering programs surrounding wages, hours and working conditions. Movement toward increased accountability and transparency and efforts to collaborate with labor organizations and associations appeared to diminish under the Trump Administration.

\subsection{MARCH 2021 UPDATE: PRELIMINARY CHANGES UNDER THE BIDEN ADMINISTRATION}

On November 3, 2020, the United States elected Joseph Biden as President, replacing Donald Trump effective January 20, 2021. In the U.S. system, top agency officials must be nominated by the President and approved by the Senate. Former Boston Mayor Marty Walsh was nominated by President Biden to be the new labor secretary; he was confirmed by the Senate on March 
22. Legislation must be approved by both bodies of Congress, and even regulations written by agencies can require months or even years to be revised. Thus, it will take many more months before the Biden Administration can modify the labor environment significantly. However, it is clear that in many areas discussed in this chapter, the Biden Administration intends to make major changes in U.S. labor policy. Here are a few highlights:

- The Biden Administration fired the two top attorneys at the National Labor Relations Board, the federal agency that regulates most private sector labor relations, and suspended ten guidance memos on collective bargaining issued by the Trump Administration. ${ }^{21}$

- President Biden proposed increasing the minimum wage from $\$ 7.25$ per hour to $\$ 15.00$ per hour, although it is not clear if there is currently sufficient congressional support for such legislation to be enacted. ${ }^{22}$

- It is likely that worker protection under the Fair Labor Standards Act will be expanded in a number of ways, including expansion of the population required to receive overtime premiums when working more than 40 hours per week; increased classification of workers as "employees" rather than independent contractors, and thus subject to additional protection; and modification of the Trump Administration's rule on "joint employers," which permits large employers to avoid provisions of the Fair Labor Standards Act under some circumstances. ${ }^{23}$

- Regarding workplace safety and health, on January 21 , the day after he was inaugurated, President Biden issued an executive order to strengthen worksite protection against the COVID-19 virus. In addition to issuing the updated guidance, the order directed OSHA to consider an emergency temporary standard related to COVID-19. The standard was issued on June 17,2021 , and became effective on that date. ${ }^{24}$

Although it will take time to see the full extent of changes in workforce policy under the Biden Administration, it is clear that an effort will be made to reverse many of the policies implemented during the Trump Administration through personnel changes, executive orders, regulations, and legislation.

\section{NOTES}

1. For discussions covering programs and policies since the 1960 s, see Barnow and Smith (2016).

2. Robert Kuttner's 1999 book Everything for Sale: The Virtues and Limits of Markets provides an excellent discussion of the particular emphasis on what he terms "market worship" in the U.S. In addition, Upton Sinclair's 1905 novel, The Jungle, highlighted deplorable working conditions for immigrants and others in the meatpacking industry and spurred legislative and regulatory reforms, as did the disastrous Triangle Shirtwaist Factory fire in 1911 in which scores of women and 
children working in New York City's garment district died. Ida Tarbell and other journalists labeled "muckrakers" wrote extensively about poor wages and working conditions in this period. Weinberg and Weinberg (2001) offer a collection of their writings.

3. Lord Keynes was reported to have asked to meet with President Roosevelt during a visit to the United States in the mid-1930s to discuss his ideas and to encourage him to adopt policies to counteract the depression more forcefully, but Roosevelt declined. The two never met.

4. Chapters by Richard Nathan and Eli Ginzberg in Ray Marshall's 2000 volume Back to Shared Prosperity review lessons from public job creation efforts in the United States.

5. One exception is that the unemployment insurance (UI) office included research staff who conducted their own research and evaluations and also funded some external research and evaluation activities.

6. More information on these studies can be found on the CEO website at USDOL: https://www.dol.gov/agencies/oasp/evaluation, retrieved August 20, 2021.

7. See D'Amico et al. (2004), Barnow (2009), and King and Barnow (2011).

8. Career pathways are defined in Section 3 of the statute. Training and Employment Notice 39-11 (TEIN 39-11) issued by the Employment and Training Administration states that "Career pathways programs offer a clear sequence of education coursework and/or training credentials aligned with employer-validated work readiness standards and competencies." TEIN 39-11 has links to information about career pathways programs. The approach has been adopted by the U.S. Department of Labor, the U.S. Department of Education, and the U.S. Department of Health and Human Services. Sectoral programs provide training for an industry sector, presumably with significant input from sector employers.

9. Under WIA, states had to receive permission from DOL to transfer funds among the Adult and Dislocated Worker programs. Although such transfers were originally routinely approved, in the final years of WIA, USDOL was more rigid. See Barnow and Hobbie (2013).

10. The WIA statute required that USDOL conduct an impact evaluation, but the requirement was not met for nearly a decade.

11. All results on the WIA evaluation are from Fortson et al. (2017).

12. This section draws upon the King and Prince chapter in the book on HPOG training, Pathways to Careers in Healthcare, edited by King and Hong (2019).

13. Fein (2012) provides a useful framework for understanding career pathways and their expected outcomes.

14. Although Year Up has very strong earnings impacts and each local program is sectorally based, it does not incorporate a career pathways approach.

15. For an in-depth discussion of this history, see Barnow and Smith (2016), and King and Barnow (2011).

16. Quoted from the administrative history of the USDOL's Employment Standards Administration: http://www.archives.gov/research/guide-fed-records/groups/448 .html, retrieved August 20, 2021.

17. See https://www.dol.gov/agencies/whd/about, retrieved August 26, 2021. A list of the many statutes the WHD is responsible for administering and enforcing can be found at: www.dol.gov/agencies/whd/laws-and-regulations/laws, retrieved August 26, 2021.

18. For example, see Weil $(2008,2009)$. 
19. A condition that applies in many other USDOL agencies and throughout the federal government three years into the Trump Administration.

20. Both the Obama Administration and the Trump Administration started initiatives to promote apprenticeship. Space limitations preclude a discussion in this chapter, but little is known at this time about the effectiveness of either initiative.

21. https://www.natlawreview.com/article/biden-puts-thumbprint-nlrb-and-begins-to -unwind-trump-board-policies, retrieved March 6, 2021.

22. Most federal legislation requires a super majority of 60 votes in the Senate, and President Biden's party only has 51 votes.

23. https://www.barclaydamon.com/alerts/what-employers-can-expect-under-the -biden-administration-fair-labor-standards-act, retrieved March 6, 2021.

24. https://www.safetyandhealthmagazine.com/articles/20798-the-first-step-osha -updates-covid-19-guidelines-as-biden-administration-focuses-on-worker-safety, retrieved March 6, 2021; https://www.osha.gov/coronavirus/ets, retrieved August 20, 2021.

\section{REFERENCES}

Barnow, Burt (2009), "Vouchers in U.S. Vocational Training Programs: An Overview of What We Have Learned", Journal for Labor Market Research 42, 71-84.

Barnow, B. and Hobbie, R.A. (eds) (2013), The American Recovery and Reinvestment Act: The Role of Workforce Programs. Kalamazoo, MI: W.E. Upjohn Institute for Employment Research.

Barnow, B. and Smith, J. (2016), "Employment and Training Programs," in R.A. Moffitt (ed.), Economics of Means-Tested Transfer Programs in the United States, Vol. 2. Chicago, IL: University of Chicago Press, pp. 127-234.

Bradley, D. (2013), The Workforce Investment Act and the One-Stop Delivery System. CRS Report for Congress. Washington, DC: Congressional Research Service.

Bruck, H., Popham A., and Stupica-Dobbs M. (2019), "Pairing Program Administration with Evaluation to Build Evidence: The Health Professions Opportunity Grants Program and Federal Evaluation Portfolio," in Christopher T. King and Philip Hong (eds), Pathways to Careers in Healthcare. Kalamazoo, MI: W.E. Upjohn Institute for Employment Research, pp. 67-103.

Clague, E. and Kramer, L. (1976), Manpower Polices and Programs: A Review, 1935-75. Kalamazoo, MI: W.E. Upjohn Institute for Employment Research.

Colvin, A.J.S. (September 27, 2017), The Growing Use of Mandatory Arbitration: Access to the Courts Is Now Barred for More Than 60 Million American Workers. Washington, DC: Economic Policy Institute (updated April 2018).

Conway, M., Blair, A., Dawson, S.L., and Dworak-Munoz, L. (2007), Sectoral Strategies for Low Income Workers: Lessons from the Field. Washington, DC: Aspen Institute, Workforce Strategies Initiative.

D'Amico, R., Dunham, K., Henderson-Frakes, J. et al. (2004), The Workforce Investment Act after Five Years: Results from the National Evaluation of the Implementation of WIA. Oakland, CA: Social Policy Research Associates.

Darling, M., O'Leary, C.J., Perez-Johnson, I.L. et al. (2017), Using Behavioral Insights to Improve Take-up of a Reemployment Program: Trial Design and Findings. Washington, DC: Mathematica Policy Research.

Eyster, L. and Gebrekristos, S. (2018), Fulfilling the Promise of Career Pathways. Washington, DC: The Urban Institute. 
Fein, D.J. (2012), Career Pathways as a Framework for Program Design and Evaluation: A Working Paper from the Pathways for Advancing Careers and Education (PACE) Project. OPRE Report No. 2012-30. Washington, DC: Office of Planning, Research, and Evaluation, Administration for Children and Families, U.S. Department of Health and Human Services.

Fein, D. and Hamadyk, J. (2018), Bridging the Opportunity Divide for Low-Income Youth: Implementation and Early Impacts of the Year Up Program. OPRE Report No. 2018-65. Washington, DC: Office of Planning, Research, and Evaluation, Administration for Children and Families, U.S. Department of Health and Human Services.

Fortson, K., Rotz, D., Burkander, P. et al. (2017), Providing Public Workforce Services to Job Seekers: 30-Month Impact Findings on the WIA Adult and Dislocated Worker Programs. Washington, DC: Mathematica Policy Research.

Gelber, A., Isen, A. and Kessler, J. (2016), "The Effects of Youth Employment: Evidence from New York City Summer Youth Employment Program Lotteries." Cambridge, MA: National Bureau of Economic Research (NBER Working Paper No. 20810).

Ginzberg, E. (2000). "Public Service Employment: A Look Back and a Look Ahead," in Ray Marshall (ed.), Back to Shared Prosperity: The Growing Inequality of Wealth and Income in America, Armonk, NY: M.E. Sharpe, pp. 287-92.

Glosser, A., Judkins, D., and Morrison, C. (2017), Workforce Development Council of Seattle-King County Health Careers for All Program: Implementation and Early Impact Report. OPRE Report No. 2017-106. Washington, DC: Office of Planning, Research, and Evaluation, Administration for Children and Families, U.S. Department of Health and Human Services.

Heller, S.B. (2014), "Summer Jobs Reduce Violence among Disadvantaged Youth," Science 346(6214), 1219-23.

Hendra, R., Greenberg, D., Hamilton, G., Oppenheim, A., Pennington, A., Schaberg, K., and Tessler, B. (August 2016), Encouraging Evidence on a Sector-Focused Advancement Strategy: Two-Year impacts from the WorkAdvance Demonstration. New York: MDRC.

King, C.T. (2014), "Sectoral Workforce and Related Strategies: What We Know ... and What We Need to Know," in Maureen Conway and Robert P. Giloth (eds), Connecting People to Work: Workforce Intermediaries and Sector Strategies. New York: American Assembly Press, pp. 209-38.

King, C.T. and Barnow, B. (2011), "The Use of Market Mechanisms," in Douglas Besharov and Phoebe Cottingham (eds), The Workforce Investment ActImplementation Experiences and Evaluation Findings. Kalamazoo, MI: W.E. Upjohn Institute for Employment Research, pp. 79-109.

King, C.T. and Hong, P. (2019), Pathways to Careers in Healthcare. Kalamazoo, MI: W.E. Upjohn Institute for Employment Research.

King, C.T. and Prince, H.J. (2015), "Moving Sectoral and Career Pathway Programs from Promise to Scale," in Carl Van Horn, Tammy Edwards and Todd Greene (eds), Transforming U.S. Workforce Development Policies for the 21st Century. Kalamazoo, MI: W.E. Upjohn Institute for Employment Research, pp. 195-229.

King, C.T. and Prince, H.J. (2019), "Career Pathway and Sector-based Strategies: A Broader Look," in Christopher T. King and Philip Hong (eds), Pathways to Careers in Healthcare. Kalamazoo, MI: W.E. Upjohn Institute for Employment Research, pp. 21-44. 
Kuttner, R. (1999). Everything for Sale: The Virtues and Limits of Markets. Chicago, IL: University of Chicago Press.

Maguire, S., Freely, J., Clymer, C., Conway, M., and Schwartz, D., (2010), Tuning in to Local Labor Markets: Findings from the Sectoral Employment Impact Study. Philadelphia, PA: Public/Private Ventures.

McNicholas, C., Sanders S., and Shierholz, H. (November 2017), What's At Stake in the States If the 2016 Raise to the Federal Overtime Pay Threshold Is Not Preservedand What States Can Do About It. Washington, DC: Economic Policy Institute.

McNicholas, C., Poydock M., and Rhinehart L. (October 16, 2019), Unprecedented: The Trump NLRB's Attack on Workers' Rights. Washington, DC: Economic Policy Institute.

Nathan, R. (2000), "Public Service Employment: Lessons from U.S. Experience in the 1970s," in Ray Marshall (ed.), Back to Shared Prosperity: The Growing Inequality of Wealth and Income in America. Armonk, NY: M.E. Sharpe, pp. 293-99.

Roder, A. and Elliott, M. (2019), Nine Year Gains: Project Quest's Continuing Impacts. New York: Economic Mobility Corporation.

Rolston, H., Copson, E., and Gardiner, K. (2017), Valley Initiative for Development and Advancement: Implementation and Early Impact Report. OPRE Report No. 2017-83. Washington, DC: Office of Planning, Research and Evaluation, Administration for Children and Families, U.S. Department of Health and Human Services.

Schaberg, K. (September 2017), Can Sector Strategies Promote Longer-Term Effects? Three-Year Results from the WorkAdvance Demonstration. New York: MDRC.

Schwartz, A.E., Leos-Urbel, J., and Wiswall, M. (2015). "Making Summer Matter: The Impact of Youth Employment on Academic Performance." Cambridge, MA: National Bureau of Economic Research (NBER Working Paper No. 21470).

Schwartz, D., Strawn, J., and Sarna, M. (2018), Career Pathways Research and Design Synthesis: Career Pathways Design Study. Bethesda, MD: Abt Associates.

Shierholz, H. (September 25, 2019), "More Than Eight Million Workers Will Be Left Behind by the Trump Overtime Rule," Economic Policy Institute. https:/www .epi.org/blog/more-than-eight-million-workers-will-be-left-behind-by-the-trumpovertime-rule-workers-would-receive-1-4-billion-less-than-under-the-2016-rule/, retrieved August 21, 2021.

United Nations Economic and Social Council, Committee of Experts on Public Administration (April 12, 2019), Relating the principles of effective governance for sustainable development to practices and results, Note by the Secretariat.

U.S. Chamber of Commerce (February 28, 2017), Restoring Common Sense to Labor Law: Ten Policies to Fix at the National Labor Relations Board.

U.S. Department of Labor (USDOL) (2010), U.S. Department of Labor Strategic Plan, Fiscal Years 2011-2016. Washington, DC: USDOL.

Weil, D. (2008), "A Strategic Approach to Labor Inspection," International Labor Review 147(4), 349-75.

Weil, D. (2009), "Rethinking the Regulation of Vulnerable Work in the USA: A Sector-Based Approach," Journal of Industrial Relations 51(3), 411-30.

Weil, D. (October 17, 2014a), The Fissured Workplace. Washington, DC: USDOL. Blog post.

Weil, D. (October 31, 2014b), Strategic Enforcement to Maximize Impact. Washington, DC: USDOL. Blog post.

Weil, D., Glass, R., Pyles, A., Min Woong Ji, and Klieve, A. (May 2010), Improving Workplace Conditions through Strategic Enforcement, a Report to the Wage and Hour Division. Boston, MA: Boston University. 
Weinberg, A. and Weinberg, L. (eds) (2001), The Muckrakers. Champaign, IL: The University of Illinois Press. 